\title{
Characteristics and performance of professionals of the Expanded Family Health and Basic Healthcare Centers
}

\author{
Características e atuação dos profissionais dos Núcleos \\ Ampliados de Saúde da Família e Atenção Básica \\ Características y actuación de los Núcleos Ampliados de \\ Salud de la Familia y Atención Básica
}

How to cite this article:

Vendruscolo C, Metelski FK, Maffissoni AL, Tesser CD, Trindade LL. Characteristics and performance of professionals of the Expanded Family Health and Basic Healthcare Centers. Rev Esc Enferm USP. 2020;54:e03554. DOI: http://dx.doi.org/10.1590/S1980-220X2018033003554

\section{Carine Vendruscolo ${ }^{1}$ \\ Fernanda Karla Metelski² \\ André Lucas Maffissoni ${ }^{3}$ \\ Charles Dalcanale Tesser ${ }^{4}$ \\ Letícia de Lima Trindade ${ }^{1}$}

${ }^{1}$ Universidade do Estado de Santa Catarina, Departamento de Enfermagem, Programa de Pós-Graduação, Mestrado Profissional em Enfermagem na Atenção Primária à Saúde, Florianópolis, SC, Brazil.

${ }^{2}$ Universidade do Estado de Santa Catarina, Departamento de Enfermagem, Florianópolis, SC, Brazil.

${ }^{3}$ Universidade Federal de Santa Catarina, Programa de Pós-Graduação em Enfermagem, Florianópolis, SC, Brazil.

${ }^{4}$ Universidade Federal de Santa Catarina, Departamento de Saúde Pública, Florianópolis, SC, Brazil.

\begin{abstract}
Objective: To analyze the characteristics and performance of the teams of the Expanded Family Health and Basic Healthcare Centers (Nasf-AB) of Santa Catarina state. Method: A multicenter study implementing mixed methods, a sample of 149 municipalities $(50.5 \%$ of the state) and 359 professionals through applying a survey and collective interviews with five teams of 43 professionals. Quantitative data were analyzed using descriptive statistics, and qualitative data were subjected to thematic analysis. Results: There were 11 professions integrated to the Centers with a predominance of psychologists (27\%), physiotherapists $(18 \%)$ and nutritionists $(18 \%)$. The professionals were mostly women (88\%) aged between 30 and 39 years $(50.4 \%)$, with their performance involving shared care, collective activities of their professional core, group activities and individual care to users. Professionals participate in the intermediation, regulation or evaluation of referrals from Primary Care to other points of the Network. The interviews revealed a set of actions of technical care and technical-pedagogical support and specialized actions. Conclusion: Despite operational difficulties, the Expanded Family Healthcare Centers have been supporting Family Healthcare teams, strengthening Primary Care.
\end{abstract}

DESCRIPTORS

Primary Health Care; Family Health; Secondary Care; Primary Care Nursing; Health Services Accessibility. 


\section{INTRODUCTION}

The Expanded Family Health and Basic Healthcare Centers (Nasf-AB - Núcleos Ampliados de Saúde da Família e Atenção Básica) constitute a policy developed to stimulate consolidation of Primary Healthcare (PHC), or Primary Care (PC) in Brazil, through composing multiprofessional teams aimed at interdisciplinary cooperation and resoluteness at this point of the Healthcare Network (RAS-Rede de Atenção à Saúde) $)^{(1)}$. Professionals from different specializations work from the matrix support perspective with Family Health teams (ESF - Equipes de Saúde da Familia), with a view to strengthening them and expanding their clinical resolvability, as well as supporting them in exercising care coordination functions. The diversity of professions that can be integrated into generalist teams gives Nasf the possibility to perform interdisciplinary activities, considering the knowledge of the specific nuclei of each profession as well as the knowledge field of healthcare which is common to various professions ${ }^{(2)}$.

Inspired by the Paideia model ${ }^{(3)}$ with a methodology for reformulating traditional management mechanisms and focusing on training people and forming relationships, support activates communication spaces and joint deliberation implying knowledge sharing and organizes flows. The matrix activity of the specialized team can occur in two interfaces: technical-pedagogical support, which aims to promote continuing education movements for generalist professionals; and clinical-care support, in which professionals perform clinical care upon specific demand ${ }^{(1,4-5)}$. The care coordination function has also been strengthened and highlighted in European reforms of PHC, converging with the Brazilian model. Collaboration between PHC generalists and specialists has been proposed in several countries as a strategy to qualify care, however, teams with several specialists (Nasf-AB) are members at this point of the RAS only in Brazil ${ }^{(6-7)}$.

Regarding the development of the nuclei in a national context, studies $^{(8-11)}$ reveal this device as a transformer in the work process in PHC/PC. Such direction can mobilize and impact hegemonic health practices which develop in devaluating public service scenarios and distort established power lines. As it is a support device, Nasf can change the team's own work products, which sets a new way of producing healthcare ${ }^{(12)}$.

In May 2018, 5,293 Nasf teams operating in Brazilian municipalities were identified, of which 289 are in Santa Catarina state $(\mathrm{SC})^{(13)}$. Each team can be composed of a number of professionals depending on the configuration, which varies according to the modality (Nasf 1,2 or 3) and the workload, also respecting the occupations indicated by the Ministry of Health $(\mathrm{MoH})$ for the minimal team composition, as well as local ESF priorities and needs which receive support ${ }^{(1,14)}$.

The new National Primary Healthcare Policy (PNAB - Politica Nacional de Atenção Básica) did not bring about major structural changes in the Nasf-AB, but changed its nomenclature, as it was previously called the Family Health
Support Center (NASF). Withdrawing the term support left doubts as to the matrix logic, besides the fact of expanding the responsibility of the Center for the so-called traditional PH $(e A B)$ teams ${ }^{(1,15)}$. However, the normative trajectory of Nasf is not automatically reflected in the different local realities of the Brazilian territory, so much so that the new proposition has not yet been fully assumed in some municipalities of SC state that were part of this study. For some authors, the change in PNAB leaves doubts for managers as to the place occupied by matrix support after 10 years of the Centers ${ }^{(15)}$. From this contextualization, the question is: how are the professionals who work in the Nasf-AB in SC characterized, and how do they work in the context of PHC? Thus, this study aims to analyze the characteristics and performance of Nasf-AB teams of SC.

\section{METHOD}

\section{Study Design}

A descriptive study in which production and data analysis was used implementing a quanti-qualitative approach, and an exploratory and sequential strategy. Quantitative data (QUAN) were collected and analyzed at first, and then the qualitative information (qual) was produced and analyzed considering the initial quantitative results (QUAN $\rightarrow$ qual). Conducting a study of mixed methods does not mean conducting separate research which addresses a specific question, but rather employing different methods to answer the question with complementary information ${ }^{(16)}$. The study was developed by researchers from five universities of SC (two public, two community and one private), with the participation of the State Secretariat of Health.

\section{SCENARIO}

The study scenario was the state of SC, composed of 295 municipalities distributed in the nine health macroregions. From this total, 277 municipalities had the Nasf implanted, and the Nasf members who participated in the QUAN phase of the research belong to 149 (53.8\%). municipalities which are members of all macroregions: Greater West, with 38 (50.7\%) municipalities; Midwest with 21 (48.8\%); Northeast with 9 (100\%); Greater Florianópolis with 13 (33.3\%); Foz do Itajaí with 6 (50\%); Vale do Itajaí with 23 (57.5\%); Serra Catarinense with 6 (60\%); South with 30 (75\%); and Planalto Norte with 3 (33.3\%). The population was collected from the website of the National Register of Health Facilities (CNES - Cadastro Nacional de Estabelecimentos de Saúde), totaling 1,312 Nasf members in the state in July/2017. The following participated for the 'qual' stage: 26 professionals from two municipalities of the Greater West; nine from a municipality of Greater Florianópolis; four from a municipality of Vale do Itajaí; and four from a municipality of Serra Catarinense.

\section{SAMPLE}

The sample of the QUAN stage was composed of 359 participants distributed in the nine health macroregions of 
SC. The sample size calculation considered $95 \%$ for the confidence interval and $4.5 \%$ for the margin of error. The sample for the 'qual' stage consisted of 43 Nasf members distributed in five municipalities of four Health Macroregions.

\section{Data collection}

The data were obtained in two steps. For the QUAN stage, the Nasf members were asked to answer a Survey instrument with 19 questions (closed, open and Likert questions), including sociodemographic and socio-labor data, work tools and performance demands. The collection took place between May and June 2017. The instrument underwent an instrument test with a team of professionals from the state of Paraná in order to evaluate consistency and language, and obtained a high Cronbach's alpha coefficient $(\alpha=0.819)$.

In the 'qual' stage, interviews were conducted between September and November 2017 with five teams representing the Macroregions, being established by random draw and according to access feasibility. Information production was closed according to saturation. The interviews lasted an average of 2 hours, conducted by an interviewer, a reporter (making notes on the profile and sequence of speakers) and supporters (circulating around the room with the recorders), and were recorded and transcribed in full.

\section{SeleCtion CRITERIA}

It was necessary to be active in Nasf and to agree to the Informed Consent Form to participate, which allowed access to the Survey. Professionals who were away for any reason during the collection period were excluded. In the 'qual' stage, the inclusion criteria of the participants were: to work in Nasf teams in one of the selected municipalities and to have been working on the team for at least 6 months. The exclusion criterion included: professionals away from work for any reason. The invitation to participate was sent to the Nasf members of the selected municipalities by state Macroregion, and the collective interviews were held with those who were willing to participate.

\section{DATA ANALYSIS AND PROCESSING}

The QUAN analytical procedure was performed by coding and tabulation in the Excel program with the aid of the Statistical Package for the Social Sciences (SPSS), version 21.0. The variables were described by central tendency and dispersion measures: mean, standard deviation, median and minimum and maximum values, estimation by confidence interval for the population mean based on the number of valid answers, considering the level of significance equal or less than $5 \%$ and a confidence interval of $95 \%$ or greater. Categorical variables were described by absolute frequencies and proportions.

The information underwent a thematic analysis ${ }^{(17)}$. The pre-analysis of the produced material was performed by starting with a fluctuating reading of the speech transcriptions in order to constitute the corpus of the information. Then, it went to the exploratory phase, which resulted in the first coding to reach the comprehension/meaning nuclei of the text. Finally, the text was cut into registration units, which gave rise to three categories: "services offered by Nasf- $\mathrm{AB}$ in SC"; "Collective activities/groups developed at the Nasf-AB"; "Nasf-AB intermediation for specialized care".

Chart 1 illustrates the synthesis of the methodological aspects.

Chart 1 - Synthesis of the methodological aspects.

\begin{tabular}{|c|c|c|}
\hline \multirow{3}{*}{$\begin{array}{l}\text { Study } \\
\text { design }\end{array}$} & \multicolumn{2}{|c|}{$\begin{array}{l}\text { Mixed method research with } \\
\text { sequential exploratory strategy }\end{array}$} \\
\hline & Quantitative - QUAN & Qualitative - qual \\
\hline & Cross-sectional study & Thematic analysis \\
\hline $\begin{array}{l}\text { Specific } \\
\text { objective }\end{array}$ & $\begin{array}{c}\text { Analyze } \\
\text { sociodemographic, socio- } \\
\text { work, and daily activity } \\
\text { characteristics. }\end{array}$ & $\begin{array}{l}\text { Identify the nuclei } \\
\text { of understanding of } \\
\text { interdisciplinary practices } \\
\text { and support to ESF. }\end{array}$ \\
\hline Participants & 359 Nasf members & 43 Nasf members \\
\hline $\begin{array}{l}\text { Data } \\
\text { collection }\end{array}$ & $\begin{array}{c}\text { Survey instrument with } 39 \\
\text { questions }\end{array}$ & Collective interviews \\
\hline $\begin{array}{l}\text { Data } \\
\text { analysis }\end{array}$ & $\begin{array}{c}\text { Data encoding and } \\
\text { tabulation in Excel } \\
\text { Statistical Package for the } \\
\text { Social Sciences (SPSS), } \\
\text { version } 21.0 \\
\text { Descriptive statistics }\end{array}$ & $\begin{array}{c}\text { Pre-analysis } \\
\text { Exploratory phase } \\
\text { Coding }\end{array}$ \\
\hline
\end{tabular}

\section{ETHICAL ASPECTS}

The study was approved by the Ethics Committee on Research with Human Beings of the Universidade do Estado de Santa Catarina, under Opinion No. 1.812.835/2016 and respects all the ethical precepts and current Brazilian legislative guidelines. Participants were informed about the study and their identities are preserved by identifying the speeches by professional category, followed by the numerical sequence, the term Nasf- $\mathrm{AB}$ and the order number representing the macroregion (Psychologist1/Nasf-AB1, Nutritionist1/Nasf-AB2 ...).

\section{RESULTS}

\section{Characterization of professionals Working at the Nasf-AB In Santa Catarina}

The QUAN stage was attended by 359 professionals, who together worked in $149(50.50 \%)$ of the 295 municipalities of SC. Most were female $(n=315 / 88 \%)$, with a prevalent age range of 30 to 39 years $(n=173 / 50.4 \%)$, average of 33.6 years, with a standard deviation of 7.6 years. The minimum age was 22 and the maximum was 59 years old. The most frequent level of education was lato sensu postgraduate $(n=256 / 71.5 \%)$ and the maximum degree was Doctorate $(n=1 / 0.6 \%)$.

Most participants $(n=165 / 46.1 \%)$ had worked in the Centers for more than 3 years and exclusively in Nasf-AB within the Health Department of the municipality ( $\mathrm{n}=206 / 57.5 \%)$.

Regarding the professional category, the data reveal at least 11 different professions in the Nasf-AB, highlighting the number of psychologists $(n=96 / 27 \%)$, physical therapists $(n=$ $65 / 18.3 \%)$ and nutritionists $(n=63 / 17.7 \%)$. The less frequent 
professionals were veterinarians $(n=1 / 0.3 \%)$, occupational therapists $(n=2 / 0.6 \%)$ and health workers $(n=3 / 0.8 \%)$.

Data reveal initiatives on the search for specific formation and continuing education, however they show little or no incentive from the manager:

(...) colleagues who have a master's or postgraduate degree were because they went after, the municipality does not support this much (Physical Educator/Nasf-AB1).

(...) I had the introductory course at the unit with new [professionals], but they have little ability to understand the work of Nasf (Psychologist/Nasf-AB5).

\section{Performance of the Nasf members in the context of THE PHC/PH IN SC}

In the first category of services offered by Nasf-AB in $\mathrm{SC}$, the frequency of care to users in a shared way with other professionals from Nasf/AB and ESF, or individually when the professional provides care to a user alone, usually within their specific professional core was analyzed. "Daily", there is a higher number of individual visits by the Nasf-AB (41.3\%) compared to the shared mode (15.7\%), which can be seen in Table 1. For the periodicity "up to 3 times per week", the frequency of shared care increases to $48.8 \%$ (including the percentage of "daily"), while it reaches $85.9 \%$ if the frequency of shared care "up to biweekly" is considered. Individual care "up to 3 times a week" reaches $71.96 \%$ (including the percentage of "daily"), and up to $85.9 \%$ of professionals every two weeks.

Table 1 - Service offered at Nasf-AB in Santa Catarina, Brazil, 2017.

\begin{tabular}{lc}
\hline \multicolumn{2}{l}{ Shared mode user support between Nasf-AB and ESF } \\
\hline Frequency & $\mathbf{n}(\%)$ \\
\hline Daily & $56(15.7)$ \\
Up to 3 times per week & $118(33.1)$ \\
Up to 2 times per month & $132(37.1)$ \\
Rarely & $45(12.6)$ \\
Never & $5(1.4)$ \\
\hline TOTAL & $\mathbf{3 5 6}(\mathbf{9 9 . 2} \%)$ \\
\hline Individual user service by Nasf-AB & \\
\hline Frequency & $\mathbf{n}(\%)$ \\
\hline Daily & $147(41.3)$ \\
Up to 3 times per week & $109(30.6)$ \\
Up to 2 times per month & $38(10.7)$ \\
Rarely & $49(13.8)$ \\
Never & $13(3.7)$ \\
\hline TOTAL & $356(99.2 \%)$ \\
\hline
\end{tabular}

In the shared service to the user performed collaboratively through an exchange of knowledge among professionals, some specificities that signal the potential of the centers in changing the work process of the $\mathrm{FH} / \mathrm{AB}$, mainly related to the dialogical connection with the ESF, were clarified:

(...) when I talk about the support we would like to give [to the Family Health (FH) teams], it would be through these specific tools: case discussion, construction of a therapeutic project (...) The discussion was resisted when we first proposed it because there was a change in the work process for the teams. Being able to share, being able to build something interdisciplinary (...) there is still a resistance to working together. Sometimes, even due to a lack of preparation, we know that they are several categories, so until you can build a work system that guarantees ethical issues, respects issues, the difference in points of view (...) (Nutritionist 1/Nasf-AB1).

(...) In some cases we can talk [with the ESF] about patients, but not with everyone, some we have better access to (...) (Speech Therapist 1/Nasf-AB4).

We do the shared care, too, there are situations that I need the presence of the psychologist. We agree at a time when both can, call the patient and we meet together, it's very easy (Social Worker1/Nasf-AB2).

(...) as far as possible we are always trying to make that contact and also bridging so that the $[\mathrm{FH}]$ sees the importance of talking to secondary care (Pharmacist1/Nasf-AB4).

Interviews clarify some core specificities of individual care:

Individualized care by physiotherapy happens more in the screening, directed to the outpatient clinic (Physiotherapist1/Nasf-AB4).

We do [individualized care]! Not that it is a psychological service, it is not a clinical service, but we do the first listening (...) (Social Worker1/Nasf-AB7).

(...) I can't do individual care, I do very little, so what I work, basically, is group. When I do individual care it is more for guidance or at most a return visit (Nutritionist1/Nasf-AB4).

I do individual care based on a few appointments, I can't do the longitudinal monitoring; if the patient has the need, I talk to the doctor to make the referral (...) if I start taking on individual care, I won't be able to handle the therapeutic groups (...) (Nutritionist1/Nasf-AB3).

The second category, collective activities/groups developed in the Nasf-AB, demonstrates that the groups have been developed together with the ESF from the specific area of training of the Nasf members or not. Collective activities/ groups specific to the training area are carried out "daily" and "up to three times a week" more frequently than non-specific training areas (Table 2).

Table 2 - Collective activities/groups with users at Nasf-AB in conjunction with ESF in Santa Catarina, Brazil, 2017

\begin{tabular}{lc}
\hline \multicolumn{2}{l}{ Specific to the training area of the Nasf member } \\
\hline Frequency & $\mathbf{n}(\%)$ \\
\hline Daily & $39(10.9)$ \\
Up to 3 times per week & $114(31.9)$ \\
Up to 2 times per month & $139(38.9)$ \\
Rarely & $60(16.8)$ \\
Never & $5(1.4)$ \\
\hline TOTAL & $357(99.4 \%)$ \\
\hline NOT Specific to the training area of the Nasf member \\
\hline Frequency & $\mathbf{n}(\%)$ \\
\hline Daily & $12(3.4)$ \\
Up to 3 times per week & $71(20.0)$ \\
Up to 2 times per month & $189(53.2)$ \\
Rarely & $74(20.8)$ \\
Never & $9(2.5)$ \\
\hline TOTAL & $355(98.9)$ \\
\hline
\end{tabular}


Excerpts from interviews show particularities of shared or collaborative activities performed by Nasf-AB teams and their relationship with $\mathrm{FH} / \mathrm{AB}$ :

There are food rebabilitation groups, which happen in all [Health] Units per cycle, around three to four months, then close one cycle and start another. Patients with the same profile for each group. We work with shared consultation for those who can't be met individually, make a group (...) and we give support to any group in the unit that needs it (Nutritionist1/Nasf-AB1).

Our way of acting as Nasf in physiotherapy would be, for example, to have certain types of pathology that we can jointly create therapeutic groups (...) the unit [ESF] brings the demand, we, together with the unit or with other Nasf professionals, we create groups to serve collectively (Physiotherapist1/Nasf-AB3).

(...) We don't do psychotherapy, as is traditionally offered in the office. It's not Nasf's role: it monitors until the HDG groups are opened, which is the formation of the Human Development Groups (Psychologist1/Nasf-AB1).

The third identified category, intermediation by Nasf-AB for specialized care, reveals that individualized care can lead to referral to specialized care, or even intermediation, regulation or referral assessment. Table 3 presents these results. It is observed that the option "rarely" prevails for the percentage of referrals to specialized care by the Nasf-AB, as well as the intermediation, regulation or evaluation of referrals by the Nasf members for specialized care. These data suggest that while the Nasf-AB has been offering individual and collective care actions (shared, in which part of the support is realized or not), the Nasf members on the other hand also have the potential to guide referrals, conduct intermediation, regulation or evaluation of relatively underexplored referrals (about $50 \%$ of professionals never or rarely do), to contribute to a flow that organizes and makes referrals to other points of the RAS more resolute. This makes it possible to reflect on Nasf-AB acting as a team midway between $\mathrm{PH}$ and secondary care.

Table 3 - Referrals to specialized care conducted by Nasf-AB in Santa Catarina, Brazil, 2017.

\begin{tabular}{lc}
\hline Referrals performed by Nasf members & $\mathbf{n}(\%)$ \\
\hline Frequency & $18(5.1)$ \\
\hline Daily & $48(13.5)$ \\
Up to 3 times per week & $124(34.8)$ \\
Up to 2 times per month & $141(39.6)$ \\
Rarely & $25(7.0)$ \\
Never & $356(99.2 \%)$ \\
\hline TOTAL & $\mathbf{n}(\%)$ \\
\hline Intermediation, regulation or evaluation of referrals from Primary \\
Care to specialized care & $25(7.1)$ \\
\hline Frequency & $47(13.4)$ \\
\hline Daily & $102(29.1)$ \\
Up to 3 times per week & $132(37.7)$ \\
Up to 2 times per month & $44(12.6)$ \\
Rarely & $350(97.5 \%)$ \\
Never & \\
\hline TOTAL & \\
\hline
\end{tabular}

The collective interviews presented some particularities and differentiations about these referral and regulation issues, including a notion of the Nasf as a team which, although having mastery of specific knowledge, feels part of Primary Care in a work that is (or should be) providing support and empowerment of the generalist team:

We [Psychologists] have the referrals: users come to the doctors and nurses, they make the referral, not all of them can discuss it with us before referring [for specialized attention]. They usually give preference to the most serious cases, which need a little more urgent attention (Psychologist1/Nasf-AB1).

(...) I make the referral and give it to the reception girls who schedule with the clinic; [the user] doesn't return to the doctor. Now it's changing, because it opened a physiotherapy regulation, so the patients are going there first, they leave the unit, they go to the regulation and they decide if they go to the clinic (Physiotherapist1/Nasf-AB4).

(...) we have a meeting [with teams from $\mathrm{FH}$ ] to discuss matrix support; these cases are raised and guidance is given to see what you will do for that situation, what type of referral, based on the discussion (Social Worker1/Nasf-AB5).

(...) We wouldn't want to function as a specialized core in Primary Care, but rather that we could empower professionals to qualify so they meet a more special demand. (Nutritionist1/ Nasf-AB1).

\section{DISCUSSION}

The surveyed professionals follow the general feminization trend of the health professions ( $88 \%$ women) and are relatively young. Most have a postgraduate degree, almost half have worked for more than three years, and just over half have worked exclusively in the Nasf. There are few studies on the professional profile for comparison. With regard to training, a recent study ${ }^{(18)}$ analyzed the work in Nasf in the Brazilian territory using data from the $P M A Q$ and presented unsatisfactory data regarding specific training and continuing education, referred to as being offered by management for some or for no professionals by about $50 \%$ of the teams, which therefore requires professional initiative.

Although the QUAN part involves professionals from more than half of the municipalities, it is possible that the research selected a fraction which had greater involvement with the work by full dedication, which makes generalizing the results for the set of Nasf of the state and the country unreliable. Even so, the results illuminate aspects of a significant fraction of the professionals' routines, whose work is generally strongly influenced by the local and municipal context. The highlighted professions are typically the most demanded in PHC, consistent with the prevalence of mental, musculoskeletal and cardiovascular health problems (psychologists, physiotherapists, nutritionists).

The performance of Nasf-AB is the subject of different interpretations, taking different configurations according to locality. There are controversies and doubts related to the functions of each professional area in these Centers, while showing ambiguities in the support references of practices in 
this new organizational arrangement. One of the paradoxes is the fact that there are concerns in establishing guidelines for "intra-area" action; however, the initiative is precisely oriented in the multi and interdisciplinary articulation, which implies collaboration between different knowledge and core competencies of each profession ${ }^{(19)}$. The performance of professionals in SC seems to follow that proposed by the ministerial documents ${ }^{(1,5)}$, with characteristics of technical-care and technical-pedagogical support to the ESF and some (to a lesser extent) having roles as articulators and regulators of access to specialized health services.

The data show the presence of individual care performed by most of the Nasf members, daily (Table 1 ). However, a considerable portion, more than $70 \%$, of professionals also express their work in groups, collectively with the ESFs or within their center's competence. Apparently, the meetings and joint work with ESF have been constituted (Table 2), with specificities in each team.

Interprofessional practice implies collaborative ways of working among professionals from different knowledge centers, regrouping fragmented knowledge in order to improve service delivery and avoid duplicating care. Such action is linked to the notion of teamwork and negotiation of decision-making processes through collective knowledge construction, respect for differences and singularities of knowledge and practice centers, in addition to the sum or integration of disciplinary or professional approaches ${ }^{(20-21)}$. In this perspective, it should be clarified that advances are recognized in the path towards interprofessionality, taking into account the complexity of the matrix support proposal, especially considering collaborative practices among Nasf professionals, and these with those of the ESF.

The performance in groups, specific or not, in the training area of the Nasf member is highlight. The group practices are based or should be based on interactive references which enable user participation and promotes their approach to the objectives intended by the group, reinforcing the why and the theme of each meeting. This pedagogical perspective is based on liberating education, in view of learning from the experience of others ${ }^{(22)}$. With this design, group practices can be considered devices for the promotion, prevention and the pursuit of happiness, as tools which provide bonding, accountability, expanding care, as well as not involving high technology, which contributes to cost reduction ${ }^{(23)}$.

The Nasf members seem to seek to consolidate their supportive function without disregarding the specialized clinic, according to the ideas predicted for matrix support in the precursor writings of the Nasf proposal ${ }^{(24)}$ from the 1990s. The exercise of specialized clinical care was fully assumed and added to the support and continuing education role for the ESF, both constituting (support to the teams and exercise of the specialized clinic) matrix support ${ }^{(25)}$.

The Nasf-AB was conceived as a proposal to fulfill the matrix support function in integrative care management. However, it takes time for links to be strengthened and action strategies to be formulated which meet the expectations of ESF professionals and the users themselves. On the other hand, there is concern of professionals (and researchers of the subject ${ }^{(25)}$ to avoid the Nasf members prioritizing specialized care, and especially that they do it by default and disconnected from the ESF in offices now within the health units.

The SC teams develop activities in which individual care is highlighted, but shared care with the ESF is also present. The qualitative data stand out in the case discussions, inserted in the routine, including through unscheduled conversations and interactions. User-focused groups, specific or not, gained evidence in the training area of Nasf members.

The Nasf members participate in the intermediation, regulation or evaluation of $\mathrm{PHC}$ referrals to other points of the Network, but in some rare cases they decide individually. The different arrangements of the teams seem to converge to some shared clinical exercise, forming collective spaces for discussion in which the team exercises the ability to analyze and intervene together, reflecting on the effects of their practices and collectively deliberating on this ${ }^{(3)}$. These provisions also refer to an integrated network where PHC is the preferred gateway and as such organizes access to other services. In the studied teams, PHC services supported by the work of Nasf-AB, coordinate access to specialized services. Some authors ${ }^{(25)}$ argue the need for another organizational format for Nasf, bringing them closer to specialized services, which could all operate by providing matrix support as much as possible ${ }^{(6-7)}$, and which could reduce the number of unnecessary referrals.

What was observed in $\mathrm{SC}$ were actions that seemed to make the preferential gateway more effective, which may lead to a desirable productive restructuring in health ${ }^{(12)}$ by taking responsibility for part of the demand and reorganizing the means of producing care by the professionals themselves in the extent of their duties and competences.

This study had some limitations, such as the difficulty of bringing together Nasf-AB professionals from all macroregions, as well as analyzing the different social contexts in which teams operate, which reflects the importance of conducting research exploring this theme. The challenges of adapting to official regulations also require further studies to analyze and understand how Nasf teams have been operating in the most diverse Brazilian territories and to evaluate the results of their interaction with the ESF.

\section{CONCLUSION}

The performance characteristics of Nasf-AB teams in $\mathrm{SC}$ are in line with what is predicted in the literature, which indicates that they have demonstrated the potential to support the ESF, and may be established as a mechanism for strengthening PHC as a care orderer in the RAS. Although it is a proposal in the construction process, the advances to date seem to be related to the action model centered on matrix support and which, in this state, materializes through shared consultations, individual service provision, in specific groups or not, of Nasf member professional category and participation in the regulation process between PHC and Secondary care.

The Nasf-AB proposal in $\mathrm{SC}$ has the potential to strengthen the work process in PHC. It is on the path towards 
interprofessionality, which gives Nasf a promising perspective for the quality of care, the resoluteness of PHC and its articulation with the RAS.

It is necessary to consider that randomized experiments were selected in this study design, oriented to analyze an

\section{RESUMO}

Objetivo: Analisar as características e a atuação das equipes dos Núcleos Ampliados de Saúde da Família e Atenção Básica de Santa Catarina. Método: Pesquisa multicêntrica, com métodos mistos, amostra de 149 municípios (50,5\% do estado) e 359 profissionais, mediante aplicação de Survey e entrevistas coletivas com cinco equipes, 43 profissionais. Os dados quantitativos foram analisados via estatística descritiva, e os qualitativos passaram por análise temática. Resultados: Encontraram-se 11 profissões integradas aos Núcleos, com predomínio de psicólogos (27\%), fisioterapeutas (18\%) e nutricionistas (18\%). Os profissionais são, majoritariamente, mulheres (88\%) com idade entre 30 e 39 anos (50,4\%), cuja atuação envolve atendimento compartilhado, atividades coletivas de seu núcleo profissional, atividades em grupos e atenção individual aos usuários. Os profissionais participam da intermediação, regulação ou avaliação de encaminhamentos da Atenção Primária para os demais pontos da Rede. As entrevistas revelam um conjunto de ações de apoio técnico-assistencial e técnico-pedagógico e atuação especializada. Conclusão: Os Núcleos Ampliados, apesar das dificuldades operacionais, têm atuado no suporte às equipes de Saúde da Família, fortalecendo a Atenção Primária.

\section{DESCRITORES}

Atenção Primária à Saúde; Saúde da Família; Atenção Secundária à Saúde; Enfermagem de Atenção Primária; Acesso aos Serviços de Saúde.

\section{RESUMEN}

Objetivo: Analizar las características y la actuación de los equipos de los Núcleos Ampliados de Salud de la Familia y Atención Básica de Santa Catarina. Método: Investigación multicéntrica, con métodos mixtos, muestra de 149 municipios (50,5\% del Estado) y 359 profesionales, mediante aplicación de Survey y entrevistas colectivas con cinco equipos, 43 profesionales. Los datos cuantitativos fueron analizados por vía estadística descriptiva, y los cualitativos pasaron por análisis temático. Resultados: Se hallaron 11 profesiones integradas a los Núcleos, con predominio de psicólogos (27\%), fisioterapeutas (18\%) y nutriólogos (18\%). Los profesionales son mayoritariamente mujeres (88\%), cuya actuación involucra atención compartida, actividades colectivas de su núcleo profesional, actividades en grupos y atención individual a los usuarios. Los profesionales participan en la intermediación, regulación o evaluación de derivaciones de la Atención Primaria a los demás puntos de la Red. Las entrevistas desvelan un conjunto de acciones de apoyo técnico asistencial y técnico pedagógico y actuación especializada. Conclusión: Los Núcleos Ampliados, pese a las dificultades operativas, están actuando en el soporte a los equipos de Salud de la Familia, fortaleciendo la Atención Primaria.

\section{DESCRIPTORES}

Atención Primaria de Salud; Salud de la Familia; Atención Secudaria de Salud; Enfermería de Atención Primaria; Accesibilidad a los Servicios de Salud.

\section{REFERENCES}

1. Brasil. Ministério da Saúde. Portaria n. 2436, de 21 de setembro de 2017. Aprova a Política Nacional de Atenção Básica, estabelecendo a revisão de diretrizes para a organização da Atenção Básica, no âmbito do Sistema Único de Saúde (SUS) [Internet]. Brasília; 2017 [citado 2018 jun. 30]. Disponível em: https://www.jusbrasil.com.br/diarios/161636273/dou-secao-1-22-09-2017-pg-68

2. Oliveira MM, Campos GWS. Matrix support and institutional support: analyzing their construction. Ciênc Saúde Coletiva [Internet]. 2015 [cited 2018 June 30];20(1):229-38. Available from: http://www.scielo.br/pdf/csc/v20n1/1413-8123-csc-20-01-00229.pdf

3. Campos GWS, Figueiredo MD, Pereira Júnior N, Castro CP. Application of Paideia methodology to institutional support, matrix support and expanded clinical practice. Interface (Botucatu) [Internet]. 2014 [cited 2018 June 30];18(1):983-95. Available from: http://www.scielo.br/ pdf/icse/v18s1/1807-5762-icse-18-1-0983.pdf

4. Brasil. Ministério da Saúde. Portaria GM n. 154, de 24 de janeiro de 2008. Cria os Núcleos de Apoio à Saúde da Família - NASF [Internet]. Brasília; 2008 [citado 2018 jun. 30]. Disponível em: http://bvsms.saude.gov.br/bvs/saudelegis/gm/2008/prt0154_24_01_2008.html

5. Brasil. Ministério da Saúde; Secretaria de Atenção à Saúde, Departamento de Atenção Básica, Núcleo de Apoio à Saúde da Família. Ferramentas para a gestão e para o trabalho cotidiano [Internet]. Brasília; 2014 [citado 2018 jun. 30]. Disponível em: http://bvsms.saude. gov.br/bvs/publicacoes/nucleo_apoio_saude_familia_cab39.pdf

6. Lythgoe MP, Abraham S. Good practice in shared care for inflammatory arthritis. Br J Gen Pract. 2016;66(646):275-7.

7. Bower P, Gilbody S, Richards D, Fletcher J, Sutton A. Collaborative care for depression in primary care. Making sense of a complex intervention: systematic review and meta-regression. Br J Psychiatry. 2006;189:484-93.

8. Macedo MAV, Ximenes-Guimarães JM, Sampaio JJC, Pereira-Morais A, Carneiro C. Análise do processo de trabalho no núcleo de apoio à saúde da família em município do nordeste brasileiro. Rev Gerenc Polit Salud [Internet]. 2016 [citado 2018 jun. 30];15(30):194-211. Disponível em: http://www.redalyc.org/pdf/545/54546742013.pdf

9. Volponi PRR, Garanhani ML, Carvalho BG. Núcleo de Apoio à Saúde da Família: potencialidades como dispositivo de mudança na Atenção Básica em Saúde. Saúde Debate [Internet]. 2015 [citado 2018 jun. 30];39(n.esp.):221-31. Disponível em: http://www.scielo.br/ pdf/sdeb/v39nspe/0103-1104-sdeb-39-spe-00221.pdf

10. Gonçalves RMA, Lancman S, Sznelwar LI, Cordone NG, Barros JO. Estudo do trabalho em Núcleos de Apoio à Saúde da Família (NASF), São Paulo, Brasil. Rev Bra Saúde Ocup [Internet]. 2015 [citado 2018 mar. 27];40(131):59-74. Disponível em: http://www.scielo.br/pdf/ rbso/v40n131/0303-7657-rbso-40-131-59.pdf

11. Raimundi DM, Ferreira FF, Lima FCA, Siqueira VCA. Analysis of Family Clinical, vision of service nurses. Rev Esc Enferm USP [Internet]. 2016 [cited 2018 June 30];50(n.spe):125-33. Available from: http://www.scielo.br/pdf/reeusp/v50nspe/0080-6234-reeusp-50-esp-0130.pdf 
12. Panizzi M, Lacerda JT, Natal S, Franco TB. Reestruturação produtiva na saúde: atuação e desafios do Núcleo de Apoio à Saúde da Família. Saúde Debate [Internet] 2017 [citado 2018 jun. 30];41(112):155-70. Disponível em: http://www.scielo.br/pdf/sdeb/v41n112/0103-1104sdeb-41-112-0155.pdf

13. Brasil. Ministério da Saúde. DATASUS. CNES - Equipes de saúde-Brasil. Competência 07/2018 [Internet]. Brasília; 2018 [citado 2017 ago. 28]. Disponível em: http://tabnet.datasus.gov.br/cgi/deftohtm.exe?cnes/cnv/equipebr.def

14. Brasil. Ministério da Saúde. Portaria n. 3.124, de 28 de dezembro de 2012. Redefine os parâmetros de vinculação dos Núcleos de Apoio à Saúde da Família (NASF) Modalidades 1 e 2 às Equipes Saúde da Família e/ou Equipes de Atenção Básica para populações específicas, cria a Modalidade NASF 3, e dá outras providências [Internet]. Brasília; 2012 [citado 2018 jun. 25]. Disponível em: http://bvsms.saude. gov.br/bvs/saudelegis/gm/2012/prt3124_28_12_2012.html

15. Melo EA, Miranda L, Silva AM, Limeira RMN. Dez anos dos Núcleos de Apoio à Saúde da Família (Nasf): problematizando alguns desafios. Saúde Debate [Internet]. 2018 [citado 2018 dez. 20];42(1):328-40. Disponível em: https://scielosp.org/article/sdeb/2018. v42nspe1/328-340/pt/

16. Santos JLGS, Erdmann, AL, Meirelles BHS, Lanzoni GMM, Cunha VP, Ross R. Integrating quantitative and qualitative data in mixed methods research. Texto Contexto Enferm [Internet]. 2017 [cited 2018 June 30];26(3):e1590016. Available from: http://www.scielo.br/pdf/tce/v26n3/ en_0104-0707-tce-26-03-e1590016.pdf

17. Minayo MCS. O desafio do conhecimento: pesquisa qualitativa em saúde. 14ª ed. São Paulo: Hucitec; 2014.

18. Brocardo D, Andrade CLT, Fausto MCR, Lima SML. Núcleo de Apoio à Saúde da Família (NASF ): panorama nacional a partir de dados do PMAQ. Saúde Debate [Internet] 2018 [citado 2018 dez. 20];42(1):130-44. Disponível em: http://www.scielo.br/pdf/sdeb/v42nspe1/01031104-sdeb-42-spe01-0130.pdf

19. Correia PCL, Goulart PM, Furtado JP. A avaliabilidade dos Núcleos de Apoio à Saúde da Família (Nasf). Saúde Debate [Internet]. 2017 [citado 2018 jun. 30];41(n.esp):345-59. Disponível em: http:/www.scielo.br/pdf/sdeb/v41nspe/0103-1104-sdeb-41-nspe-0345.pdf

20. Araújo TAM, Vasconcelos ACCP, Pessoa TRRF, Forte FDS. Multiprofissionalidade e interprofissionalidade em uma residência hospitalar: o olhar de residentes e preceptores. Interface (Botucatu) [Internet]. 2017 [citado 2018 dez. 22];21(62):601-13. Disponível em: http://www. scielo.br/pdf/icse/v21n62/1807-5762-icse-1807-576220160295.pdf

21. D'Amour D, Goulet L, San Martín-Rodrigues LS, Pineault R. A model and typology of collaboration between professionals in healthcare organizations. BMC Health Serv Res [Internet]. 2008 [cited 2018 June 30];8:188. Available from: https://www.ncbi.nlm.nih.gov/pmc/ articles/PMC2563002/

22. Maceno PR, Heidemann ITSB. Unveling the actions of nurses in primary health care groups. Texto Contexto Enferm [Internet]. 2016 [cited 2018 June 30];25(4):e2140015. Available from: http://www.scielo.br/pdf/tce/v25n4/0104-0707-tce-25-04-2140015.pdf

23. Freitas FB, Seminotti N, Leite JCC. Protocolo de observação: uma estratégia para capacitação em coordenação de grupos. In: Seminotti N, organizador. O Pequeno Grupo como um Sistema Complexo: uma estratégia inovadora para produção de saúde na Atenção Básica. Porto Alegre: Rede Unida; 2016.

24. Campos GWS. Equipes de referência e apoio especializado matricial: um ensaio sobre a reorganização do trabalho em saúde. Ciênc Saúde Coletiva [Internet]. 1999 [citado 2018 jun. 27];4(2):393-403. Disponível em: http://www.scielo.br/pdf/csc/v4n2/7121.pdf

25. Tesser CD. Núcleos de Apoio à Saúde da Família, seus potenciais e entraves: uma interpretação a partir da atenção primária à saúde. Interface (Botucatu) [Internet] 2016 [citado 2018 abr. 28];21(62):565-78. Disponível em: http://www.scielo.br/pdf/icse/v21 n62/18075762-icse-1807-576220150939.pdf

Fundação de Amparo à Pesquisa e Inovação do Estado de Santa Catarina (FAPESC). Granting

Agreement No. 2016TR2209. FAPESC no. 10/2015 - FAPESC/MS-DECIT/CNPQ/SES-SC - Apoio à Programa de Pesquisa para o SUS (PPSUS) - Shared Health Management. 